\title{
Financial inclusion in China: an overview
}

\author{
Weidong Chen and Xiaohui Yuan*
}

\author{
* Correspondence: yuanxiaohui@ \\ bankofchina.com \\ Research Institute, Bank of China, \\ No.1 Fuxingmennei Dajie, Xicheng \\ District, Beijing 100818, China
}

\begin{abstract}
Financial inclusion has become an important development strategy in many countries, and related research is increasing. Financial inclusion in China has had significant progress recently. It has gradually formed a unique and sustainable development path with supporting policies and regulations as well as rapid development and application of digital technology. While challenges remain, the experience of Chinese financial inclusion provides valuable lessons and research directions for policymakers and researchers.

Keywords: Financial inclusion, Digital financial inclusion, Microfinance, China
\end{abstract}

\section{Introduction}

Financial inclusion, or "inclusive finance," is the availability and equality of opportunities to access a range of appropriate financial services, such as savings, credit, payment, and risk management products, by individuals and enterprises, especially lowincome people and micro and small enterprises (MSEs). Microfinance, as the origin and pioneer of financial inclusion in the 1990s, mainly focused on serving certain segments of the excluded market with targeted products (Cobb et al. 2016; Ledgerwood et al. 2013), while financial inclusion considers everyone who is excluded and focuses on a broad range of services. Recently, there has been an increasing awareness and discussion that financial exclusion is a multi-faceted problem affecting different proportions of one country's population, including both developed and developing countries. Meanwhile, financial inclusion has become an important financial development strategy worldwide to enhance individuals' financial well-being, reduce poverty and promote economic growth (Bruhn and Love 2014).

With all kinds of consistent efforts, financial inclusion is on the rise globally. By October 2018, more than 55 countries had committed to the inclusive financial service framework, and more than 60 were planning national strategies to promote it (World Bank 2018). The Global Findex database shows that 1.2 billion adults worldwide have newly obtained an account since 2011. The percentage of adults with banking accounts rose from $62 \%$ in 2014 to $69 \%$ in 2017 in the world, with 54\% to $63 \%$ in developing economies (World Bank 2017). There have been successful and valuable examples of financial inclusion practices in many economies during this period, such as the Grameen Bank in Bangladesh, the community banks in the US, agent banking in Brazil, and

(c) The Author(s). 2021 Open Access This article is licensed under a Creative Commons Attribution 4.0 International License, which permits use, sharing, adaptation, distribution and reproduction in any medium or format, as long as you give appropriate credit to the original author(s) and the source, provide a link to the Creative Commons licence, and indicate if changes were made. The images or other third party material in this article are included in the article's Creative Commons licence, unless indicated otherwise in a credit line to the material. If material is not included in the article's Creative Commons licence and your intended use is not permitted by statutory regulation or exceeds the permitted use, you will need to obtain permission directly from the copyright holder. To view a copy of this licence, visit http://creativecommons.org/licenses/by/4.0/. 
the Agricultural Cooperatives in Japan. However, the challenges for inclusive finance remain. For example, about 1.7 billion adults in the world remain unbanked-without an account at a financial institution or through a mobile money provider (World Bank 2017).

As the second-largest economy, China has experienced great development and accumulated rich experience in inclusive financial systems. With the rapid development of the economy, reform, and transformation of the financial sector, more financial services are now provided for individuals and enterprises in China, especially MSEs and lowincome groups. According to the People's Bank of China (PBC) and China Banking and Insurance Regulatory Commission (CBIRC), by the end of June 2020, outstanding loans to MSEs and agricultural areas in China reached RMB40.7 trillion and RMB37.8 trillion, accounting for $24 \%$ and $22 \%$ of the total outstanding loan of financial institutions, respectively. As a crucial part of financial reform, financial inclusion contributed significantly to promote poverty alleviation and regional economic growth in China. Despite the rapid development of financial inclusion in China, the concept is relatively new. The penetration and sustainability of financial inclusion need to improve, and to achieve a booming market of financial inclusion in China still has a long way to go.

Thus, the current study's objective is to provide a detailed understanding of China's progress and remaining challenges of financial inclusion, and insights for scholars. The rest of this paper proceeds as follows. Section 2 presents the interests of academic researchers in financial inclusion. Section 3 introduces the policy environment and financial inclusion in China, and digital financial inclusion development. Section 4 provides a cross-country analysis based on various global datasets. Section 5 demonstrates the remaining challenges and risks in the financial inclusion practice of China. Section 6 aims to discuss potential research areas for further academic research.

\section{Literature review}

The United Nations first proposed financial inclusion in the International Year of Microcredit 2005, and the inclusive financial systems have been prospering. According to the State Council of the People's Republic of China, financial inclusion is a process by which individuals and groups access appropriate and effective financial services and products at affordable costs, based on equal opportunity and business sustainability. The focus of the current study includes the following topics.

The first topic focuses on the basic theory and concept of financial inclusion. Financial inclusion aims to include the unbanked population and groups into the financial systems, viewed as an evolving and deepening financial development (Laeven et al. 2015; Pearce 2011). Studies have shown the importance of financial accesses to economic growth and poverty reduction, as the unbanked population or groups often find it difficult to accumulate savings, invest in income-generating projects, and build assets to protect against risks (Cumming et al. 2014, 2016; Neaime and Gaysset 2018). As public goods, financial inclusion should help more vulnerable groups to access financial services at affordable costs (Beck et al. 2015; Cnaan et al. 2012). Moreover, financial inclusion should provide opportunities to share the benefits of economic growth and promote economic and social well-being. 
Second, prior studies focus on measuring the level of financial inclusion. Most studies recognize it as a multidimensional phenomenon and evaluate it by constructing index systems (e.g., Demirgüç-Kunt et al. 2015). Based on prior studies, the measurement of financial inclusion can be concluded as covering three components: access, awareness, and use. The difference and connection between them could be viewed from a supplydemand perspective. Access refers to the supply of services, i.e., the geographic reach of service outlets or accessibility of financial service (Demirgüç-Kunt et al. 2015; Han and Melecky 2013; Hannig and Jansen 2010). Awareness refers to one's financial literacy, i.e., the extent to which individuals want to or can become fully included within the financial services. On the demand side of financial inclusion, awareness can be viewed as a combination of behaviors necessary to make sound and sophisticated financial decisions and promote financial well-being (Atkinson and Messy 2013; Guo and Ding 2015). Use refers to the actual amount of financial services consumption, including savings, credit, insurance, etc. (Fungáčová and Weill 2015). Moreover, use is determined by both demand and supply of services and reflects the quality or effectiveness of financial inclusion.

Third, few studies examine the determinants of financial inclusion. From macroperspectives, socioeconomic factors, such as economic growth, population, social stability, and legal systems, are significantly influential in promoting financial inclusion (Allen et al. 2016; Kabakova and Plaksenkov 2018; Lopez and Winkler 2018). Moreover, barriers to financial inclusion differ with individual characteristics. Studies indicate that the degree of financial inclusion is determined by individual characteristics such as age, marriage, gender, and education level (Ali 2019; Allen et al. 2016; Fungáčová and Weill 2015; Nanziri 2016; Zins and Weill 2016). Higher education and income level, urban identity, being a man, and being older are significantly related to using formal bank account and credit.

Furthermore, the fourth research topic is the effect of financial inclusion. Studies have shown that financial inclusion is vital in promoting economic growth (Kim et al. 2018; Sethi and Acharya 2018; Sharma 2016), especially the regional economic activities in the remote and rural area. Meanwhile, financial inclusion acts as an incremental resolution to maintain social stability by reducing income inequality (Neaime and Gaysset 2018). Similarly, the impact of financial inclusion on employment, consumption, and production is also significant (Dupas and Robinson 2013). Some studies examine the effect of financial inclusion on credit risk (Chen et al. 2018). From individual and family perspectives, studies show that the inclusive nature of financial services can promote educational opportunities for individuals and the social credit level of families (Anzoategui et al. 2014; Chiapa et al. 2016).

Lastly, there is emerging research in recent years regarding financial inclusion in the Chinese market. Some studies focus on the reach of banking outlets and financial services by reviewing the historical development of the banking system (Bai et al. 2018; Peng et al. 2014; Sparreboom and Duflos 2012); some examine the use of formal credit in China to emphasize the importance of financial inclusion (Chen and Jin 2017; Fungáčová and Weill 2015); others study the impact of financial inclusion on commercial banks in China (Chen et al. 2018; Yang and Zhang 2020).

Accordingly, it can be concluded that financial inclusion has become important to promote economic growth and social well-being worldwide. Financial inclusion aims to 
improve the foundation and structure of financial systems by widening financial services coverage to the excluded population and groups. Although several studies focus on Chinese financial inclusion achievements, there are emerging and significant issues to be solved, owing to the rapid development of financial technology and the banking industry in China. Our study aims to contribute to the literature from three aspects. First, this study aims to provide a comprehensive outlook of China's financial inclusion progress, with perspectives from policy support, banking services, digital financial development, and cross-country assessment. Second, we emphasize the remaining risks and challenges of financial inclusion, i.e., challenges in the development of regional financial institutions, the potential risk of existing service mode, and risk of digital financial inclusion, currently faced by the Chinese banking industry. Last, based on specific Chinese practices, our study provides academic implications for further studies, from perspectives of the government support, banking system, financial stability, and financial theory evolution.

\section{Financial inclusion development in China}

Financial inclusion in China has recently undergone significant progress, with diversified service providers, extensive service coverage, and a high financial service penetration level. In pursuing the financial well-being of low-income people, MSEs, and farmers, China's financial inclusion practices have gradually formed a unique and sustainable development path.

\section{Policies and regulations}

In 2013, the Third Plenary Session of the 18th Central Committee of the Communist Party of China (CPC) explicitly announced the initiative to develop financial inclusion. On December 31, 2015, the State Council of China issued Plan for Advancing the Development of Financial Inclusion (2016-2020) (hereinafter the Plan), outlining a plan for improving the availability, satisfaction, and quality of financial services and products, emphasizing MSEs, rural residents, low-income urban people, the poor, the disabled, and the elderly, as the target customers of financial inclusion. Under the Plan, a broad range of policy measures, including monetary policies, tax policies, and supervision policies, have been taken to reduce the operational and communication cost of serving customers and encourage technology- and product-innovation, to promote financial inclusion.

\section{Monetary and credit policies}

Recently, the $\mathrm{PBC}$ has employed a range of policies, including differentiated required reserve ratios, loan refinancing, and rediscounted loans, to incentivize financial institutions to serve MSEs and the Three Rural (the agricultural sector, farmers, and rural areas) better. Since 2018, the PBC started reducing the required reserve ratios of commercial banks that have reached the required lending ratios to the underserved market segments, including MSEs (credit limit to less than RMB5 million), the Three Rural, and the poor. Until May 2020, the PBC had made targeted reductions five times and comprehensive reductions seven times. As of May 15 , 2020, the commercial banks' average reserve ratio was $9.4 \%$, down by $5.2 \%$ 
from 2018. The reserve ratio of the large, medium, and small banks was $11 \%, 9 \%$, and $6 \%$, respectively. The reduction in required reserve ratios provides commercial banks more funds to serve the real economy, including financial inclusion areas.

The $\mathrm{PBC}$ has also used lending and discounting facilities to promote financial inclusion. By the end of 2019, the outstanding amount of the targeted agriculture and targeted micro-enterprise refinancing, and the rediscounted loan was RMB260.2 billion (USD37 billion), RMB283.2 billion (USD40 billion) and RMB471.4 billion (USD68 billion), accounting for $26 \%, 28 \%$, and $46 \%$ of the total refinancing and rediscounted amount, respectively. To improve the service quality of financial inclusion, the $\mathrm{PBC}$ promoted a range of innovative policies, including pilot mortgage loans with "two rights" (farmers' housing property rights and management rights to contracted rural land) as collateral, encouraging qualified financial institutions to issue financial bonds exclusively for loans to MSEs, and encouraging MSEs to raise funds by debt financing instruments, etc.

\section{Fiscal and tax policies}

Both central and local government's support have stimulated the development of Chinese financial inclusion. The following are selected examples of fiscal and tax policies to incentivize financial inclusion.

- Earmarked funds. In September 2016, the Ministry of Finance of the People's Republic of China issued the Administrative Rules for Earmarked Funds of Financial Inclusion. These earmarked funds are provided by the central government and can be used as: (1) awards for an incremental increase in agriculture-related loans by county-level financial institutions; (2) targeted subsidies to rural financial institutions; and (3) interest subsidies for guaranteed loans to business start-ups. Moreover, some local governments established risk compensation funds to increase agriculture-related loans or loans to MSEs.

- Government-owned financing guarantee funds. China has been actively supporting local governments to establish government-owned guarantee companies to share the credit risk of MSE loans or agriculture-related lending. In March 2018, China had formally set up a national guarantee fund for more lending to MSEs and farmers through equity investment and re-guarantee on local guarantee programs. As of April 3, 2020, according to the Ministry of Finance, the fund size reached RMB49.6 billion (USD7.1 billion).

- Tax reduction. Examples of past and current tax policies include (1) value-added tax exemption and reduction of taxable income calculation by $10 \%$ for interest income of financial institutions on small loans to farmers; (2) stamp tax exemption for loan contracts between financial institutions and MSEs; (3) raising the pre-tax deduction standard for loan loss reserves; and (4) implement tax deduction for insurance companies' premium income from aquaculture and farming industry.

\section{Differentiated regulations}

Chinese authorities have actively leveraged supervisory tools to promote financial inclusion, mainly focusing on differentiated regulation and preferential policies for priority 
sectors and new market players. The PBC and CBIRC have issued various measures to improve financial inclusion. For instance, large and medium commercial banks are encouraged to set up inclusive finance departments within both headquarter and branches; financial inclusion assessment is implemented in the annual regulatory evaluation of commercial banks; and differentiated calculation and assessment of non-performing loan ratios is performed for MSE and agriculture-related loans. The non-performing loan ratios for MSE loans could be up to $2 \%$ higher than the industry-wide target, without any punishment or other adverse consequences on the financial service providers, including MSEs loans into the Macro-PrudentialAssessment framework.

Regarding the non-banking financial institutions, i.e., the securities and insurance companies, the regulatory authority aims to lower the risk of product innovation and expand the financing channels for MSEs and the poor. Recently, the China Securities Regulatory Commission (CSRC) has supported the financial needs of the small- and medium-enterprises (SMEs) by lowering the financial standards of the SME board, expanding the pilot program of Equities Exchange and Quotations to the whole country, and further expanding the pilot program of SME private equity bond. Regarding insurance industry supervision, the regulatory authority encourages the development of agriculture insurance, establishing a national agricultural insurance information platform that enhances real-time monitoring and dynamic management, and supports insurance companies to develop innovative insurance products for agricultural goods. With such insurance products, farmers can lower both natural and market risks.

\section{Progress of financial inclusion in China}

The banking industry is the main force in China's financial system, with bank lending as the most frequent financial channel for the real economy. According to CBIRC, by the end of 2019, there were 4607 banking financial institutions in China, with the total assets at RMB290 trillion (USD41.5 trillion). Under significant policy guidance, Chinese banking financial institutions have notably expanded the scale of their service networks, product uptake, and innovation. They are committed to promoting the development of financial inclusion.

\section{The physical reach of service outlets}

Access to financial services is the basic foundation to achieve financial well-being (Sinclair 2013). Chinese traditional financial service providers have historically been characterized as geographically limited and uneven. Recently, policy motivation, increased competition, and market opportunities incentivized diversified financial institutions to expand their branches' reach, especially in remote and rural areas. Based on the categories of financial service providers, there were six state-owned commercial banks, 12 joint-stock commercial banks, 134 city commercial banks, 3915 rural financial institutions (including 1478 rural commercial banks, 1630 village-township banks, 722 rural credit cooperatives, 44 rural mutual credit cooperatives, 28 rural cooperative banks, and 13 microcredit companies), and other banking financial institutions in China by the end of 2019. The branches of banking financial institutions have increased rapidly 
in recent years, with approximately 228,000 as of 2019 , which increased by $8.4 \%$ from 2013 (see Fig. 1). The number of rural financial service providers experienced rapid growth, especially the new-type rural financial institutions-village and township banks, credit companies, microcredit companies, and rural mutual credit cooperatives. The total number of outlets of the four new-type rural financial institutions reached 84,000 as of 2018. Simultaneously, financial infrastructure such as automated teller machines (ATMs) and point-of-sale (POS) has notably increased over the years, with 1.1 million ATMs and 31 million POS as of 2019.

\section{The role of village and township banks}

Village and township banks (VTBs) in China, as emerging rural banking institutions, have contributed innovatively to enhancing the coverage and depth of financial services in rural and remote areas. With the largest number of institutions and the smallest average customer size, VTBs were designed to support MSEs and farmers. Since the pilot program of VTBs initiated in 2006, the number of VTBs have increased rapidly and reached 1633 as of June of 2019, with $65.7 \%$ located in the central and western regions, covering appropriately 1300 counties of 31 provinces (municipalities, autonomous regions). More than 90\% of loans from VTBs were issued to MSEs and farmers in the local counties, and the average loan balance to a single borrower was RMB335,000 (USD48,000) by the end of September 2019.

The regulatory authorities innovatively proposed the "principal sponsor banking" to promote the sustainable and robust development of VTBs. The commercial banks meeting certain supervisory requirements were the main shareholders and the principal sponsor of VTBs, providing support and supervisions regarding corporate governance, risk management, technologies, and talents. Currently, the BOC Fullerton Community Bank, a subsidiary of Bank of China, has become the largest VTB group in China, with 125 VTBs and 166 branches located in 22 provinces by the end of 2019. With the widest range of businesses and products, the BOC Fullerton Community Bank aims to

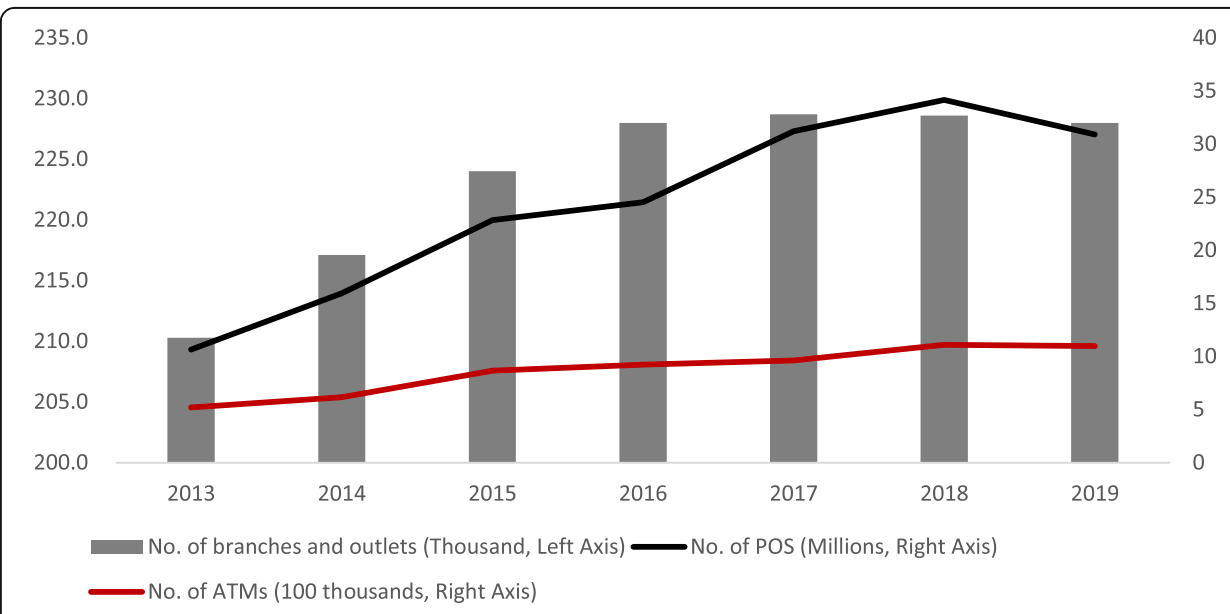

Fig. 1 Physical reach of Chinese banking financial institutions. Source: Data of the number of branches and outlets is from China Banking Association, data of the number of ATMs and POS is from the PBC 
meet the diversified and differentiated financial needs of MSEs and farmers. For instance, the agriculture-related loan products cover more than 76 items in 17 categories of agricultural goods, including aquaculture, poultry farming, etc. By the end of 2019, The BOC Fullerton Community Bank's total assets were USD9.43 billion. The total balance of deposits and loans was USD6 billion and USD6.4 billion, increased by 45 and 96 times from the end of 2011. Table 1 presents the recent three-year financial summary for the BOC Fullerton Community Bank.

\section{Ownership of banking accounts and cards}

As an important indicator of financial inclusion, owning a banking account or card enables individuals to access a broader range of financial services and develop financial awareness (Chen and Jin 2017). The foundation has been laid for opening and using the bank accounts and debit and credit cards due to the national payment and clearing systems and continuing expansion of commercial banks' networks. According to the $\mathrm{PBC}$, the number of accounts and cards issued by commercial banks increased from 2 billion and 2.8 billion in 2009 to 8.4 billion and 11.3 billion, respectively, by the end of 2019. The number of accounts and cards per capita reached 8.09 and 6.03 , by the end of 2019. The growth rate in rural areas was higher than that in urban areas, reflecting a strong penetration of banking accounts and cards in remote and rural areas.

\section{Credit use of the underserved market segments}

Traditional risk assessment in credit approval of banking financial institutions usually include acceptable collaterals, restricting the credit accessibility of MSEs and farmers owing to the narrow range of collateral coverage. To meet regulatory requirements and in response to intensive market competition, the Chinese commercial banks and other financial institutions have sought to develop innovative business models to better serve MSEs and farmers, including improving credit evaluation tools, expanding the scope of collaterals, creating new product and loan repayment approaches, etc. These efforts have notably contributed to the increasing credit use of the underserved market segments. New financing types, e.g., intellectual-property-based guaranteed loans, supply chains finance based on receivables and inventory, have grown rapidly. By the end of June 2020, the MSE and agriculture-related loan balance from banks reached RMB40.7 trillion and RMB37.8 trillion, respectively (see Fig. 2). The financial-inclusion MSE

Table 1 The three-year financial summary of the BOC Fullerton Community Bank

\begin{tabular}{llll}
\hline & $\mathbf{2 0 1 7}$ & $\mathbf{2 0 1 8}$ & $\mathbf{2 0 1 9}$ \\
\hline No. of VTBs & 95 & 125 & 125 \\
No. of branches & 118 & 142 & 166 \\
Total assets (USD billion) & 6.23 & 8.64 & 9.43 \\
Total deposits (USD billion) & 4.03 & 5.58 & 5.96 \\
Total loans (USD billion) & 3.93 & 5.62 & 6.37 \\
Net profit (USD billion) & 0.65 & 0.97 & 1.20 \\
Non-performing loan ratio & $1.66 \%$ & $2.42 \%$ & $1.68 \%$ \\
Provision coverage ratio & $245.61 \%$ & $237.80 \%$ & $254.01 \%$ \\
\hline
\end{tabular}

Source: Annual reports of the BOC Fullerton Community Bank 
loans, i.e., bank lending of under 10 million to a single borrower, reached RMB 13.73 trillion, for a year-on-year rise of $28.4 \%$, significantly higher than the average loan growth of $14 \%$.

\section{Interest cost of inclusive financing}

Generally, the high loan interest rate is an obstacle for MSEs or low-income groups to effectively obtain financing, making it difficult for potential loan seekers to raise funds from formal channels (Rice and Strahan 2010). Driven by the policy guidance and the new technology, Chinese banking financial institutions have further improved the cost and the risk-sharing mechanism. They implemented preferential policies to reduce small and dispersed inclusive financing costs within a reasonable range (Tsai 2017). According to CBIRC, the average loan interest rate for newly granted MSE loans was $5.94 \%$ in the first half of 2020. It declined by 0.76 percentage points from the average level of 2019, while the average interest rate for newly granted enterprise loans was $4.64 \%$, with a decline of 0.48 percentage points.

\section{Establishment of financial information infrastructure}

Financial information infrastructure, such as credit rating platform and guarantee system, has been a fundamental element of financial inclusion improvement, by reducing the information asymmetry and transaction risks. There has been significant progress in China's financial infrastructure improvement in recent years. First, the credit reporting system operated by the $\mathrm{PBC}$ aims to promote responsible credit to households and enterprises by reducing the information asymmetry between lenders and borrowers. The credit reference center of the PBC was launched in 2006, and it has now established the credit reporting system with the widest coverage, the world's largest data scale. By the end of 2019, 1 billion individuals and 28.3 million enterprises were included in the credit reporting system, with 53\% MSEs. Besides, new arrangements in the legal framework facilitate financial service providers to employ flexible collateral or guarantee. For instance, the development of both state-owned and private guarantee companies provide commercial banks with more options to share credit risks and conduct a comprehensive risk assessment.

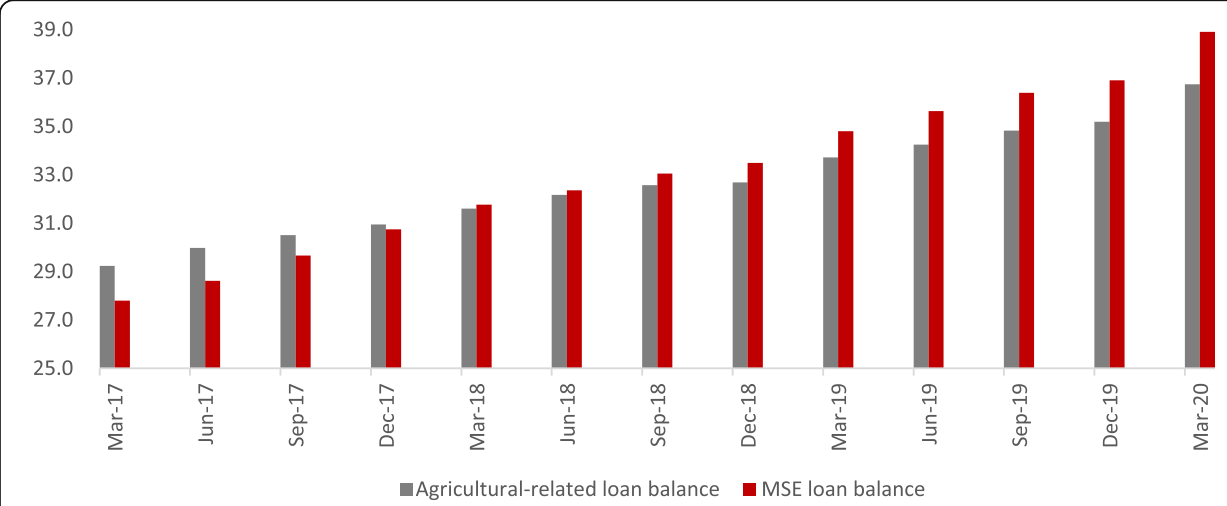

Fig. 2 MSE and agriculture-related loan balance from Chinese banking financial institutions (Unit: RMB trillion). Source: Wind; PBC; CBIRC 


\section{Development of digital financial inclusion in China}

China has recently emerged as one of the leaders in global digital finance and financial technology (FinTech). With the integration of digital technology and financial services, both traditional financial institutions and emerged Internet financial service providers have further expanded their ability to tap into traditionally unmet and neglected financial demand of consumers such as MSEs. The development of digital finance lowers the threshold of financial services and promotes operational efficiency with new models, delivery channels, and products (Huang et al. 2020; Lai et al. 2020). The main features of digital financial inclusion development in China can be demonstrated as follows.

\section{Growing digital payment}

Digital payment has significantly improved the accessibility of financial inclusion in remote and rural areas by supplementing the physical access and eliminating the geographic limitation of financial services. The transaction number and volume of both online and mobile payments maintained a good momentum of growth. Several commercial banks have built "all-in-one" financial service platforms, with various payment products, e.g., UnionPay's "Cloud Flash Payment" and Bank of China's "cross-border ecommerce direct link," and the active use of new payment technologies, e.g., use of NFC and QR codes. The digital payment of non-bank financial institutions has been flourishing, such as Alipay and WeChat Pay. Moreover, the growth rate of digital payment in the Chinese rural area was notably higher than in urban areas (see Fig. 3). According to the $\mathrm{PBC}$, the number of digital payment in rural areas, including online and mobile payments, increased from 160 billion to 309 billion during 2017-2018, near the amount in urban areas.

\section{Emerging of internet banks}

Many Internet-based enterprises have recognized the advantages of e-commerce like rich customer resources and diverse transactional data, and entered the field of Internet banking, such as WeBank and MyBank launched by Tencent and Alibaba, respectively,

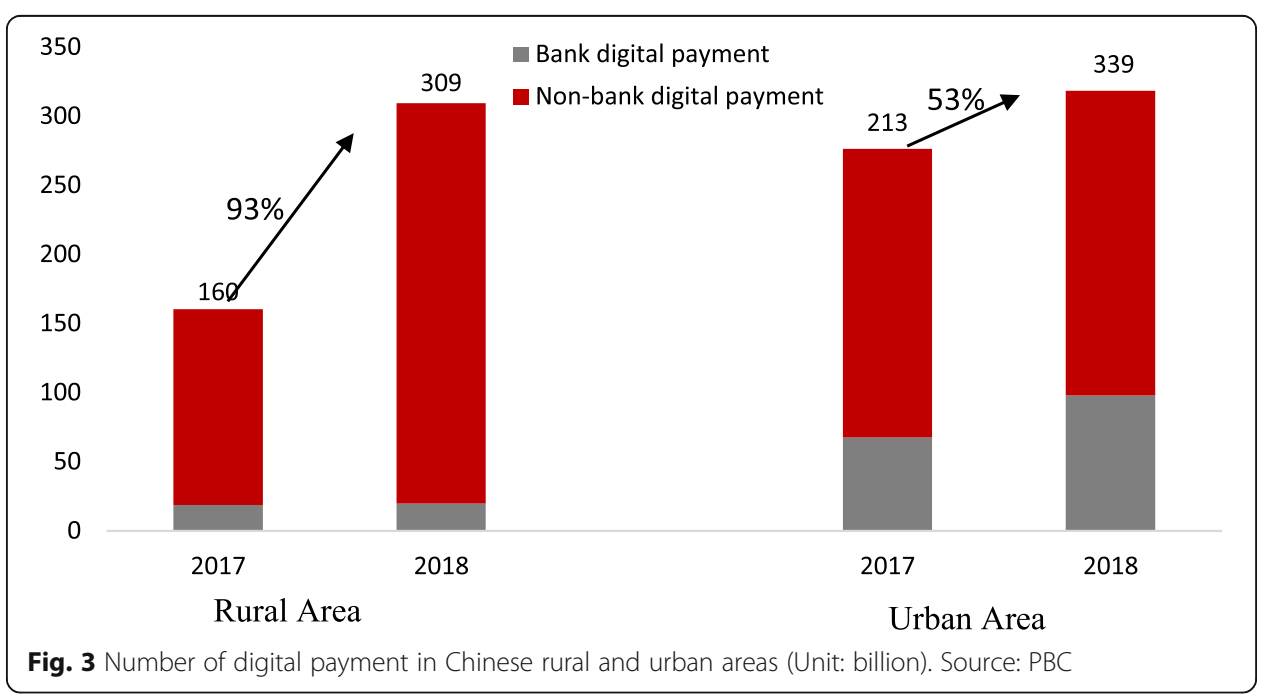


in 2015. With no physical outlets and offline services, Internet banks aim to leverage online technology platforms and data to target MSEs and individuals. For example, WeBank has two microloan products, "Weilidai" and "Weiyedai," each targeting individuals and MSEs, with the lending limit up to RMB300,000 (USD43,000) and RMB3 million (USD430,000), respectively. By the end of 2019, WeBank and MyBank, as the leading Internet banks in China, owned total assets of USD42 billion and USD20 billion each, and outstanding loans of USD23 billion and USD10 billion, respectively. Internet banks have demonstrated unique characteristics compared with traditional banks to identify and develop risk management models based on data and technology from major shareholders-the Internet-based enterprises. The business and operation models of Internet banks are still evolving and exploring, with remaining challenges and limitations. For instance, it is difficult for Internet banks to absorb deposits and other funds without a physical presence. With further exploration and regulation, Internet banks will contribute significantly to financial inclusion by more diversified product offerings and finer risk management tools.

\section{Development of internet microfinance}

The financing demand of MSEs and individuals usually represents high frequency, low amount, and urgent need. The Internet and technology facilitate financial service providers to launch more appropriate and targeted financial products for MSEs and individuals. Microfinance has been a significant force of financial inclusion recently. The rapid growth of Internet microfinance can be attributed to the rapid development of the Internet, e-commerce, and information technology. Based on different service providers, Internet microfinance in China can be divided into three categories: bank-based, e-commerce-based, and supply-chain-based. Many commercial banks have launched relevant online lending services, with online instant credit approval, no guarantee or collateral, and a low amount limit. Some Internet companies, such as Alibaba and JD, provide small loans for online shop owners and shoppers from their e-commerce platforms through micro-lending companies or Internet banks under their control. Moreover, some domestic enterprises explore the advantages of the supply-chain relationship and industrial reputation, launching e-finance platforms under the cooperation with banks, providing financial services to MSEs.

\section{Cross-country assessment of China's financial inclusion}

The following content provides a comparative cross-country analysis of financial inclusion worldwide to benchmark the progress of financial inclusion in China, based on a series of relevant global databases, including the IMF Financial Access Survey database (IMF 2018), IMF World Bank Global Payment System Survey (GPSS), World Bank Global Financial Inclusion (Findex) database, World Bank Doing Business database, World Bank Development Indicators (WDI) database, World Bank Enterprise Surveys, and G20/OECD INFE Report on Adult Financial Literacy in G20 countries.

\section{Access to financial services}

According to the IMF Financial Access Survey in 2018, the number of commercial bank branches per $1000 \mathrm{~km}^{2}$ in China was 10.8, ranking 79th of 159 countries and 
regions, higher than the United States (9.0), Brazil (3.7), Russia (1.9), Canada (0.7) and Australia (0.7) (see Fig. 4). Meanwhile, the number of commercial bank branches per 100,000 adults in China was 8.8, ranking 112th of 159 countries and regions, lagging behind the global average, OECD and BRICS. Simultaneously, the density of remote access in China is far ahead of other economies. According to the World Bank Findex survey in 2017, the number of ATMs per $1000 \mathrm{~km}^{2}$ and 100,000 adults in China was 118.3 and 96.3 , respectively, ranked 25th and 24th worldwide, respectively.

High rates of mobile and Internet access can also provide individuals and businesses with more channels to financial products and services (Chinoda and Kwenda 2019a; Evans 2018; Ouma et al. 2017). Smart mobile phone access is notably universal in China. Many emerging new financial service models in China, especially digital financial inclusion, developed mobile devices with Internet access, exploit the massive scale of digital transactions. According to the financial inclusion survey by the World Bank, 50\% of adults in China reported that they had used a mobile phone or the Internet to access a financial institution account in 2017, and the percentage is far above the average in the Asia Pacific, Euro area and the world (see Fig. 5).

The number of traditional physical access of commercial banks worldwide, such as the branch outlets, has decelerated recently. Moreover, owing to high operation cost and change of customer habits, cutting down and withdrawals of physical branches appeared in some countries. Based on data from Federal Deposit Insurance Corporation (FDIC), the total number of banking branches in the US decreased to 78,800 in 2018, from the historically highest level of 83,600. Large multinational banks in the UK have at least closed 2600 branches since 2015, including HSBC, Lloyds Banking Group, the Royal Bank of Scotland, and Barclays. Thus, thanks to the expanding mobile access to financial services supported by the increasing prevalence of smartphone and the Internet in remote and rural areas, the overall density of financial services access in China is high enough.

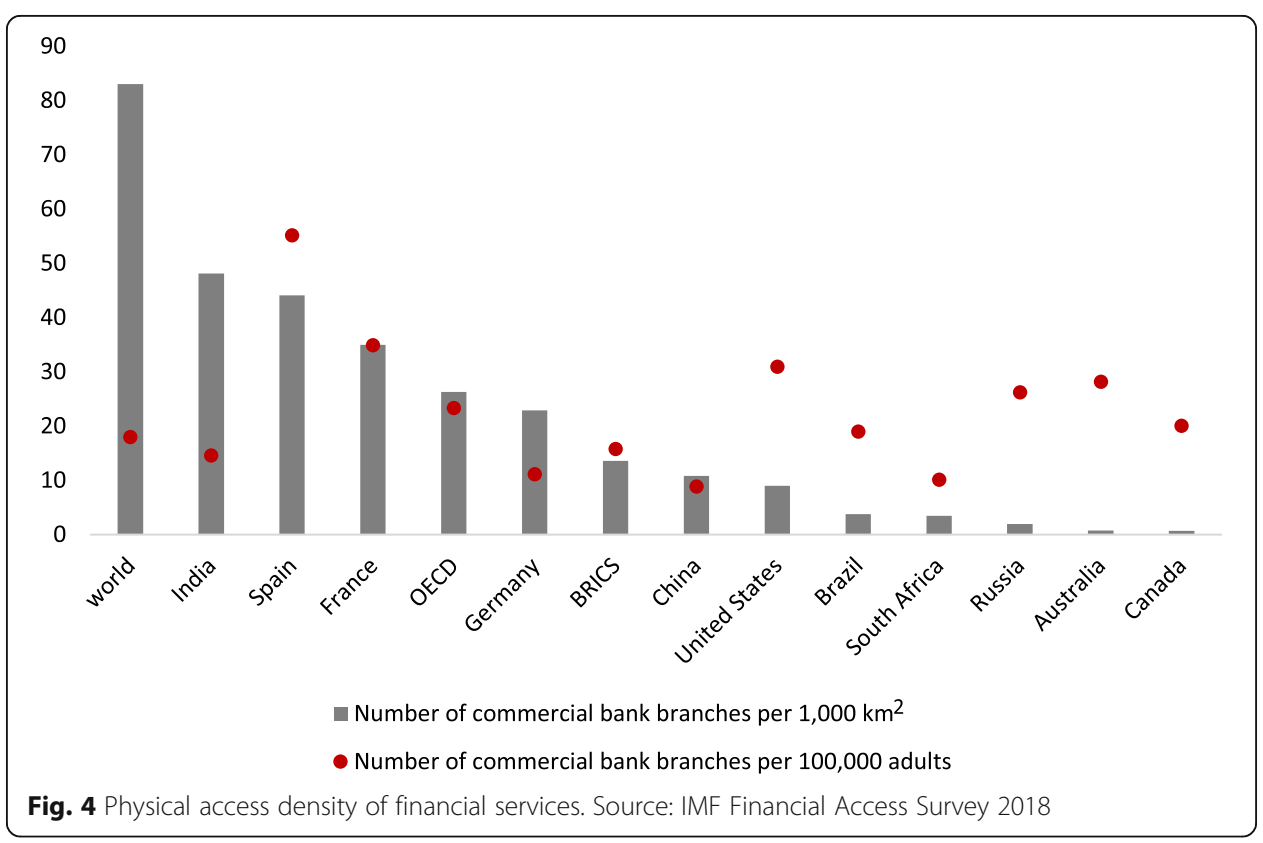




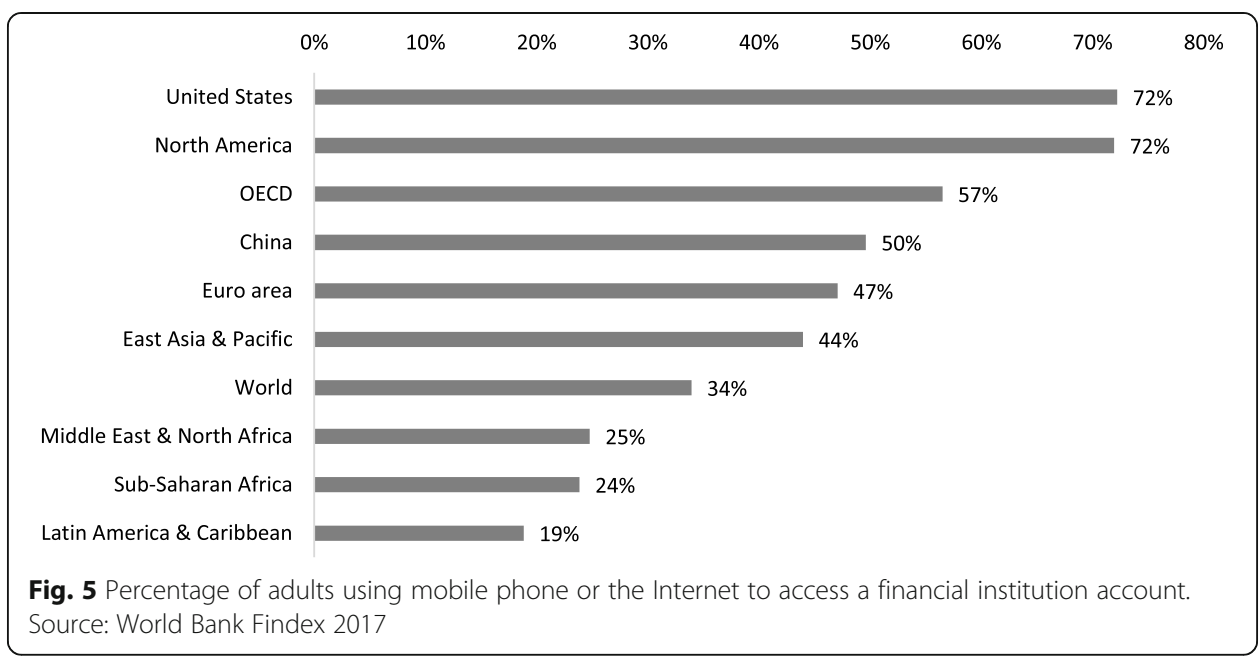

\section{Usage of financial services}

According to the World Bank Findex and Enterprise Surveys database in 2017, 80\% of individuals and $96 \%$ of China's enterprises have banking accounts in formal financial institutions, far above the global and Asia Pacific average levels. However, with the significant presence of banking accounts, the use of credit is still a challenge in China. Only $25.3 \%$ of adults in China have outstanding banking loans or credit records, lower than the global average level (33.8\%). 28\% of China's adults have borrowed from family or friends, higher than the average level in the Asia Pacific, OECD, and the world. In comparison, 23\% of China's adults have ever borrowed from formal financial service channels, roughly equivalent to the global average level and lower than the average level in Asia Pacific and OECD. For enterprises, the amount of credit used by the private sector in China is notably high, with domestic credit/GDP at $161.1 \%$ in 2018, lagging behind the US (186\%) and Japan (168.8\%). However, according to the Getting Credit score and Getting Credit rank from the World Bank (World Bank 2019), which measures the ease of getting credit, China scored 60 within the range of 0 to 100 and ranked at 80th worldwide (see Fig. 6).

\section{Individuals' financial awareness}

Financial knowledge, along with a robust consumer protection framework, is vital for individuals or enterprises to use a wide range of regulated financial products and services adequately, timely, and effectively (Adomako et al. 2016; Atkinson and Messy 2013; Grohmann et al. 2018). According to the G20 Financial Literacy Survey, three components are included: financial knowledge (grasp of basic financial concept and the ability to apply numeracy skills in the financial context), financial behavior (paying debt, budgeting, saving, and borrowing, etc.), and financial attitude (the philosophy of live-for-today spending or focusing on long-term financial security). Among all G20 countries, China has a high overall score of financial literacy at 14.1, as only three of G20 countries achieved an average score above 14 (the other two countries are France (14.9) and Canada (14.6)), indicating that Chinese consumers and enterprises have a relatively high level of financial awareness worldwide. The average score of financial knowledge, behavior, and attitude in China was 4.7, 6.2, and 3.7, respectively (see Fig. 7). 


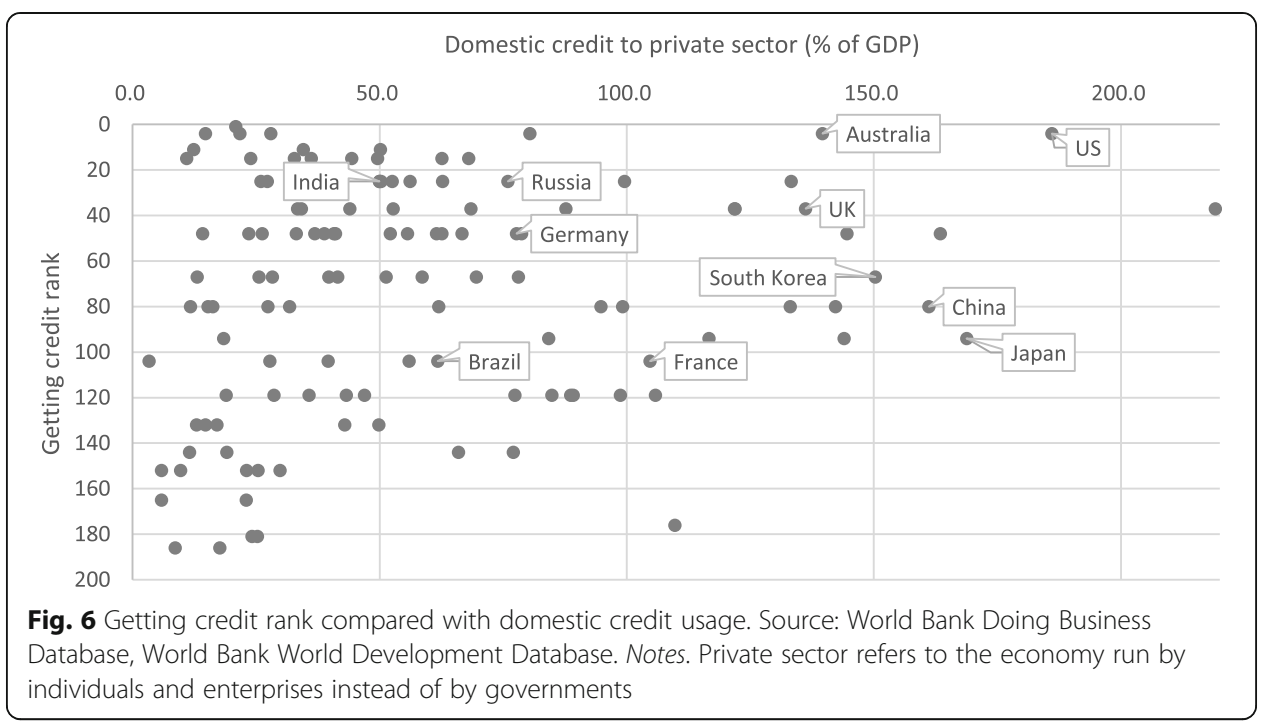

According to the G20 Adult Financial Literacy Survey, people who held savings products usually had higher financial awareness. In China, nearly $96 \%$ of adults were active savers of savings including rainy-day savings and savings for long-term goals, far above the average level of G20 countries (64\%). Saving behaviors are prevalent in China, possibly attributing to the high level of banking account ownership and convenienient deposit and withdrawal facilitated by digital platforms.

\section{Remaining risks and challenges of financial inclusion in China}

Despite the recent impressive progress of financial inclusion in China, risks and challenges remain. The increasing popularization of financial inclusion and appropriate credit and accounts usage were accompanied by strong support and guidance from policymakers and efforts by Chinese financial institutions. For many in China, financial inclusion still maintains a simple view, such as targeted lending, credit subsidies, and charitable activities, unfavorable for financial inclusion to achieve sustainable development. It is necessary to call for more commercially sustainable business models, more diverse and appropriately-designed products and services addressing different market

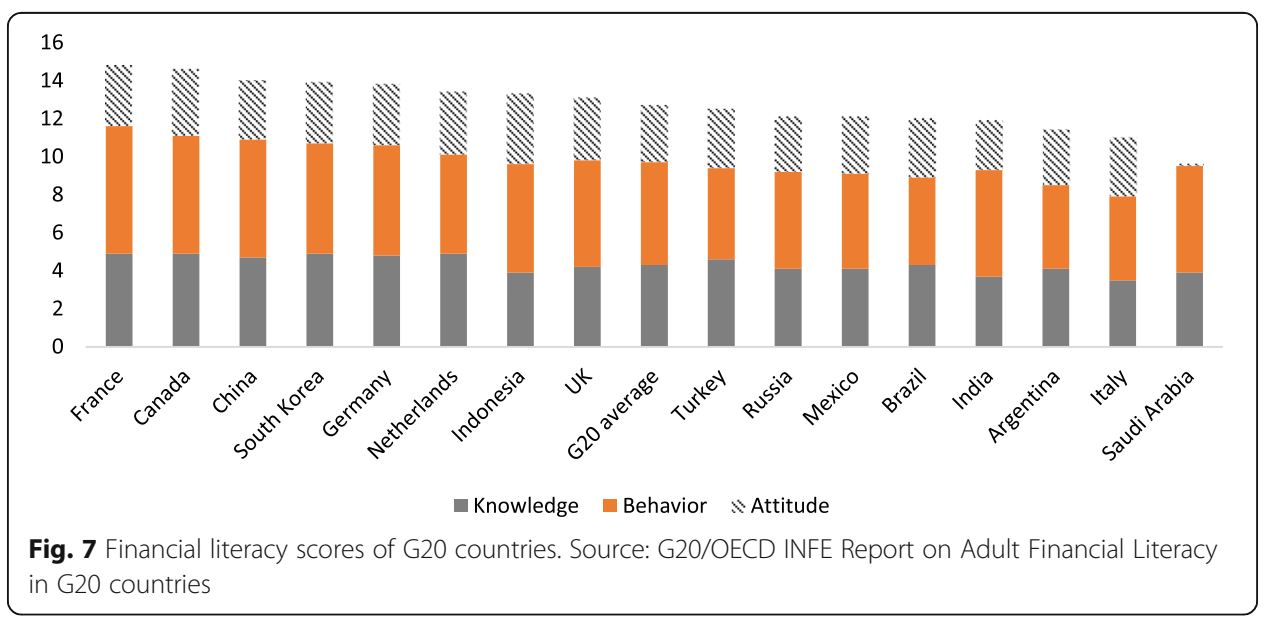


segments, and more thorough and robust financial infrastructures, including service outlets, credit rating platforms, and guarantee systems to promote the long-term financial well-being of the population and the enterprises.

\section{The role of regional financial institutions}

Due to the lack of collaterals and high information asymmetry in MSEs and lowincome groups, financial service providers need to make more efforts to effectively screen and evaluate the lending applicants, involving case analysis and long-time tracking and communications. It is globally recognized that small and medium regional financial institutions can provide more efficient and high-quality inclusive financial services through relationship banking and flexible credit approval and risk assessment systems, with the advantages of small scale and geographical proximity in local communities. For instance, the community banks in the US, with the license of State Chartered Bank, adopt the business model of "relationship banking," like credit approval with clients' soft information included as important, such as personalities, management capabilities by others' evaluation within the communities. The other well-known examples are the primary municipal cooperatives of Japan Agricultural Cooperatives and the selfformed loan-supporting group of the Grameen Bank in Bangladesh.

Chinese regional financial institutions, i.e., the city commercial banks, rural commercial banks, and the new rural financial institutions such as village and township banks, have contributed significantly and achieved financial inclusion success. Compared with large- and medium-sized commercial banks, regional financial service providers have broader service reach and closer acquaintance with the local market. Regarding SMEs, small-sized regional banks are one of the main forces, accounting for around 30\% of the outstanding loans as of June 2020, based on data disclosed by CBIRC. However, significant improvements of regional financial institutions are necessary to serve the local economy, enhance the operational capability, and contribute to financial inclusion. Long-term and sustainable financial support in the local market from regional financial institutions needs to improve further. In the past decade, many city and rural commercial banks increased profitability by setting up licensed or non-licensed business bases across regions. They expanded financing businesses such as interbank borrowing, causing a "siphon effect" by which deposits and funds in some less developed regions were invested in more developed areas. Recently, this phenomenon has experienced a significant decline owing to the tightening of regulations. The further sustainable development and risk management of some regional commercial banks remains a challenge. Some small-sized regional banks face potential barriers in areas such as corporate governance, structures of shareholders, and talent management, making it challenging for the penetration of financial services into the local market. To achieve further development, regional financial service providers should enhance their abilities in risk management, customer service, corporate governance, and product research and development.

\section{Sustainability of business model}

Affordable costs are necessary to motivate financial service providers to develop inclusive financial systems, as commercial sustainability is the basic foundation for achieving efficiency and long-term well-being. The demand for financial inclusion is dispersed 
with small-amount and high-frequency, which requires service providers to develop targeted risk management and service modes based on local markets' characteristics. It is difficult for financial institutions to operate profitably in the long-term without improved business models, due to information asymmetry, lack of collaterals, and high operation costs, especially in rural and remote areas with low-density populations and underdeveloped economies. The success of some financial products and services through digital or specific innovation has illustrated the feasibility of sustainable business models in financial inclusion. According to the $\mathrm{PBC}$, currently, the amount of traditional collateral-based lending from commercial banks still accounts for around $52 \%$ of the overall MSE loans.

\section{The potential risk of digital inclusive finance}

Though the application of digital technologies provides more opportunities to achieve long-term sustainable development of financial inclusion, risks in the current digital inclusive financial models still exist. According to a white paper by the Global Partnership for Financial Inclusion-an inclusive platform for all G20 countries, the potential risk of digital financial inclusion attributes to its inherent nature. First, the new financial service providers, such as FinTech companies or Internet banks, aim to perform the basic function of financial services as other traditional financial institutions and face the common operation, liquidity, capital adequacy, and money laundering risks. However, the innovative business model and risk management system of the new entrants could expand and heighten those risks. Second, the massive use of digital technologies can threaten the financial service providers by attracting more "high-risk customers" and employing an Internet-based business model (Ozili 2018). Also, it increases the difficulty of consumer protection relevant to the possible abuse and loss of customer information and privacy. For example, the intrusion of computers or networks through viruses increases illegal use and personal information theft. Furthermore, the development of digital financial inclusion increases the use of agents and third-party platforms as an important interface with customers, instead of traditional service outlets. However, the real-time, interactive, borderless nature of this service heightens the spread of possible financial risk across companies and industries.

The emergence and development of digital financial inclusion pose new challenges to regulation systems. By extensive expansion of digital finance, some large Internet-based companies, such as Alibaba and Tencent, established financial service platforms with various products including lending, insurance and wealth management, and heightened the difficulty of regulation on Internet-based mixed financial operations. Consistent effort in supervisory evolution and innovation of regulation tools and approaches is necessary to address these emerging challenges. In July 2015, the release of Guidelines on Promoting Sound Development of Internet Finance by the PBC had laid the foundation and standards for appropriate regulation. The potential risks related to digital financial inclusion could extend across financial inclusion itself and affect the soundness, safety, and long-term well-being of the overall financial system. Recently, China has implemented a series of policies and guidelines to cope with the increasing risk of peer-topeer lending and cash lending, which improves the legal and regulatory framework (Li et al. 2020). 
Moreover, digital technologies can be used to control financial risks. Regulatory authorities worldwide, including those in China, have been exploring digital technologies to manage the risks, i.e., through the RegTech (regulatory technology). For instance, regulation reporting platforms can promote the frequency and accuracy of financial regulation by expanding the data collection and possibly achieving real-time monitoring and supervision.

\section{Academic implications for further research}

Despite the plentiful research focusing on the concept, determinants, and effect of financial inclusion as aforementioned, significant and interesting issues remain and need to be solved by further research, according to China's practices.

\section{The role of government in financial inclusion}

China's financial inclusion progress cannot be separated from the government's function, including monetary policies, fiscal and taxation policies, regulations, etc. Fundamentally, financial exclusion is a sign of market failure (Aggarwal and Klapper 2013; Atkinson and Messy 2013), comprising both the supply and demand sides. There are studies highlighting the role of government intervention (Aggarwal and Klapper 2013; Chen and Divanbeigi 2019; Mehrotra and Yetman 2014). Though financial inclusion is embedded in each country's unique political, cultural, and economic context, China's success and challenges can provide lessons in implementing financial inclusion for other countries and regions. Further studies can examine the function of government intervention on financial inclusion, such as the effect of fiscal or taxation policies on the accessibility or usage of financial services.

\section{Connection between the banking system and financial inclusion}

Currently, banking industries are the main force of financial services in many countries. The characteristics of banking systems should have a direct effect on the progress of financial inclusion. Studies prove that competition within the banking industry has a significantly positive effect on financial inclusion (Chinoda and Kwenda 2019b). Also, the banking industry concentration was significantly associated with access to banking accounts and credit (Owen and Pereira 2018). Studies show that the size of the banking system cannot improve financial inclusion (Turegano and Herrero 2018). Moreover, there are studies examining the effect of banking systems on financial inclusion, e.g., the effect of rural banking (Aggarwal and Klapper 2013), Islamic banking (Naceur et al. 2017), and the entry of foreign banks (Leon and Zins 2020). From the authors' perspective, China has experienced significant progress in the financial market and sectors, especially in the banking industry ${ }^{1}$ and the effect of foreign banks on financial inclusion could be a hot research topic, given the booming financial inclusion market and the increasing competition of foreign banks in the Chinese market.

${ }^{1}$ In May 2019, CBIRC released 12 measures for enhancing finance openness in the banking and insurance industry; in July 2019, the State Council released 11 measures for financial openness; and in September 2019, the State Council released the revised version of Regulations on the Administration of Foreign-Funded Banks. 
Nexus between financial inclusion and corporate performance

Existing literature has proved the nexus between financial inclusion and economic development (Gul et al. 2018; Kim et al. 2018; Sethi and Acharya 2018; Sharma 2016). However, the nexus between financial inclusion and corporate performance need to be addressed at the micro-enterprise level. There can be three potential mechanisms or channels through which financial inclusion influences corporate performance. First, it can affect the entry decision by promoting economic growth in remote and rural areas. Second, it may provide extra investment opportunities in some industries, such as the agricultural industry, by long-term financial services under government support. Third, it can promote corporate innovation, as many innovative MSEs can gain sustainable financial support through financial inclusion.

\section{Relationship of financial stability with financial inclusion}

Although several studies have proven the positive effect of financial inclusion, it has some challenges. The main reason for implementing financial inclusion is that there are many traditional "unbanked" individuals and businesses. Therefore, it is necessary to consider the associated risks of financial stability. By achieving a fully-serving financial inclusion system, the effect of the potential financial crisis might be magnified, as more individuals and enterprises will be exposed to financial risks with a large population relying on credit use. Moreover, innovations in financial inclusion enhanced the integration of technology and financial services, and the connection between the formal and informal financial sectors. The collapse of the payment system may have a contagious and spillover effect among financial systems. Several studies on the relationship between financial stability and financial inclusion have been conducted (Hannig and Jansen 2010; Morgan and Pontines 2014; Neaime and Gaysset 2018), while the empirical studies remain rare. Moreover, the relationship between financial stability and financial inclusion remains unclear across studies, and the backbox of the relative effect remains unsolved.

\section{The role of financial inclusion in financial theory}

The emergence and Chinese practices of financial inclusion can provide insights and realistic evidence for relative theoretical extensions. First, it presents additional proofs contributing to the theoretical arguments in the finance-growth nexus. From "supplyleading" perspectives, there have been empirical studies verifying the positive effect of financial development on economic growth (e.g., Cheng 2012; Cooray 2010), based on the theoretical foundation of financial liberalization pioneered by Shaw (1973) and McKinnon (1973) suggesting that accumulation of financial assets leading to economic growth. From the "demand-following" perspective, some scholars hold that the role of financial development is negligible and insignificant to trigger economic growth (Samargandi et al. 2015). Regarding Chinese financial inclusion practice, financial inclusion should be considered within the arguments on finance-growth nexus. Further studies can focus on the mechanism of financial inclusion, financial development, and economic growth.

Second, the financial intermediation theories advocate that financial intermediaries can overcome market frictions and information asymmetry to effectively transferring 
funds from savers to borrowers rather than direct lending or investing (Beck et al. 2007; Diamond 1984). Financial inclusion aims to reduce the transaction costs of financing MSEs and the poor to achieve financial deepening. Chinese financial inclusion practice implies that moral hazard and information monopoly can be reduced by providing a government-based guarantee system and establishing national financial infrastructure. Based on the aforementioned potential relationship between financial inclusion and financial stability, the question has been brought forth that the circumstances under which financial inclusion helps enhance financial intermediaries' functions by promoting financial deepening or leads to financial instability by exposing more population to financial risks. Further research should consider the role of financial inclusion when employing financial intermediation theoretical models.

\section{Conclusion}

Chinese financial inclusion has been experiencing significant progress in recent years. There is a need for more systematic research on this topic, although some introductory studies have been conducted on financial inclusion, rural finance, and digital financial inclusion. This paper provides a comprehensive and thorough outlook of China's financial inclusion progress, with perspectives from policy support, banking services framework, digital financial development, and cross-country assessment. Based on the banking practices of financial inclusion in recent years, we conclude the remaining risks and challenges of financial inclusion in China. This paper provides further research directions for researchers, i.e., the role of government and banking services in financial inclusion, financial inclusion-stability nexus, and financial theory evolution.

There are several key takeaways. First, China's government support in regulation, monetary policy, and fiscal policy has played an important role in developing financial inclusion. Second, the Chinese banking industry is the main service provider of financial inclusion. Compared with state-owned banks, regional banks' efforts in financial inclusion need to be improved. Third, compared with other economies, China's development of financial inclusion is above the global average, especially in digital financial inclusion and individuals' financial awareness. Last, the development of digital financial inclusion has significantly promoted the efficiency of financial services, although the remaining challenges and potential risks are noteworthy.

\section{Abbreviations \\ ATMs: Automated teller machines; BOC: Bank of China; CBIRC: China Banking and Insurance Regulatory Commission; CBRC: China Banking Regulatory Commission; CSRC: China Securities Regulatory Commission; FDIC: Federal Deposit Insurance Corporation; GPSS: Global Payment System Survey; IMF: International Monetary Fund; MSEs: Micro and small enterprises; OECD: The Organization for Economic Co-operation and Development; PBC: People's Bank of China; POS: Point-of-sale; SME: Small and medium enterprises; VTBs: Village and township banks}

\section{Acknowledgements}

The authors would like to thank an anonymous referee and the editor for very valuable comments on an earlier version of this paper. All errors are the author's sole responsibility.

Authors' contributions

All authors listed on the title page have contributed significantly to the work, have read the manuscript, attest to the validity and legitimacy of the data and its interpretation, and agree to its submission. The author(s) read and approved the final manuscript. 


\section{Availability of data and materials}

The dataset used and/or analysed during the current study are available from the corresponding author on reasonable request.

\section{Competing interests}

The authors declare that they have no competing interests.

Received: 23 June 2020 Accepted: 13 January 2021

Published online: 22 March 2021

\section{References}

Adomako, S., Danso, A., \& Ofori Damoah, J. (2016). The moderating influence of financial literacy on the relationship between access to finance and firm growth in Ghana. Venture Capital, 18(1), 43-61.

Aggarwal, S., \& Klapper, L. (2013). Designing government policies to expand financial inclusion: Evidence from around the world. The Journal of Finance, 56(3), 1029-1051.

Ali, A. E. E. S. (2019). Empowering women through financial inclusion: Some evidence from Comoros. International Journal of Asian Social Science, 9(2), 25270.

Allen, F., Demirgüç-Kunt, A., Klapper, L., \& Pería, M. S. M. (2016). The foundations of financial inclusion: Understanding ownership and use of formal accounts. Journal of Financial Intermediation, 27(C), 1-30.

Anzoategui, D., Demirgüç-Kunt, A., \& Pería, M. S. M. (2014). Remittances and financial inclusion: Evidence from El Salvador. World Development, 54, 338-349.

Atkinson, A., \& Messy, F. (2013). Promoting financial inclusion through financial education. OECD Working Papers on Finance, Insurance and Private Pensions, No. 34.

Bai, D., Jiang, R., Wang, T., Chien, J., \& Randall, D. (2018). Toward universal financial inclusion in China: Models, challenges and global lessons. Washington DC: World Bank Publications.

Beck, T., Demirgüç-Kunt, A., \& Levine, R. (2007). Finance, inequality and the poor. Journal of Economic Growth, 12(1), 27-49.

Beck, T., Senbet, L., \& Simbanegavi, W. (2015). Financial inclusion and innovation in Africa: An overview. Journal of African Economies, 24(suppl_1), i3-i11.

Bruhn, M., \& Love, I. (2014). The real impact of improved access to finance: Evidence from Mexico. The Journal of Finance, 69(3), 1347-1376.

Chen, F. W., Feng, Y., \& Wang, W. (2018). Impacts of financial inclusion on non-performing loans of commercial banks: Evidence from China. Sustainability, 10(9), 3084.

Chen, R., \& Divanbeigi, R. (2019). Can Regulation Promote Financial Inclusion?. World Bank Policy Research Working Paper No. 8711.

Chen, Z., \& Jin, M. (2017). Financial inclusion in China: Use of credit. Journal of Family and Economic Issues, 38(4), 528-540.

Cheng, S. Y. (2012). Substitution or complementary effects between banking and stock markets: Evidence from financial openness in Taiwan. Journal of International Financial Markets, Institutions and Money, 22(3), 508-520.

Chiapa, C., Prina, S., \& Parker, A. (2016). The effects of financial inclusion on children's schooling, and parental aspirations and expectations. Journal of International Development, 28(5), 683-696.

Chinoda, T., \& Kwenda, F. (2019a). The impact of institutional quality and governance on financial inclusion in Africa: A twostep system generalized method of moments approach. Journal of Economic and Financial Sciences, 12(1), 1-9.

Chinoda, T., \& Kwenda, F. (2019b). Do mobile phones, economic growth, bank competition and stability matter for financial inclusion in Africa? Cogent Economics \& Finance, 7(1), 1622180.

Cnaan, R. A., Moodithaya, M. S., \& Handy, F. (2012). Financial inclusion: Lessons from rural South India. Journal of Social Policy, 41(1), 183-205.

Cobb, J. A., Wry, T., \& Zhao, E. Y. (2016). Funding financial inclusion: Institutional logics and the contextual contingency of funding for microfinance organizations. Academy of Management Journal, 59(6), 2103-2131.

Cooray, A. (2010). Do stock markets lead to economic growth? Journal of Policy Modeling, 32(4), 448-460.

Cumming, D., Johan, S., \& Zhang, M. (2014). The economic impact of entrepreneurship: Comparing international datasets. Corporate Governance: An International Review, 22(2), 162-178.

Cumming, D., Rui, O., \& Wu, Y. (2016). Political instability, access to private debt, and innovation investment in China. Emerging Markets Review, 29, 68-81.

Demirgüç-Kunt, A., Klapper, L., Singer, D., \& van Oudheusden, P. (2015). The global Findex database 2014: Measuring financial inclusion around the world. Policy Research Working Papers. Washington, DC: The World Bank.

Diamond, D. W. (1984). Financial intermediation and delegated monitoring. The Review of Economic Studies, 51(3), $393-414$.

Dupas, P., \& Robinson, J. (2013). Why don't the poor save more? Evidence from health savings experiments. American Economic Review, 103(4), 1138-1171.

Evans, O. (2018). Connecting the poor: The internet, mobile phones and financial inclusion in Africa. Digital Policy, Regulation and Governance, 20(6), 568-581.

Fungáčová, Z., \& Weill, L. (2015). Understanding financial inclusion in China. China Economic Review, 34, 196-206.

Grohmann, A., Klühs, T., \& Menkhoff, L. (2018). Does financial literacy improve financial inclusion? Cross country evidence. World Development, 111, 84-96.

Gul, F., Usman, M., \& Majeed, M. T. (2018). Financial inclusion and economic growth: A global perspective. Journal of Business \& Economics, 10(2), 133-152.

Guo, T., \& Ding, X. (2015). An international comparative study of inclusive finance-From the perspective of bank services. Studies of International Finance, 2, 55-64.

Han, R., \& Melecky, M. (2013). Financial inclusion for financial stability: Access to bank deposits and the growth of deposits in the global financial crisis. In World Bank Policy Research Working Paper No.6577.

Hannig, A., \& Jansen, S. (2010). Financial inclusion and financial stability: Current policy issues. In Asian Development Bank Institute Working Paper, 259, (pp. 1-29). 
Huang, J., Chai, J., \& Cho, S. (2020). Deep learning in finance and banking: Literature review and classification. Frontiers of Business Research in China, 14, 1-24.

IMF (2018). Financial access survey. Retrieved from https://data.imf.org/?sk=E5DCAB7E-A5CA-4892-A6EA-598B5463A34C.

Kabakova, O., \& Plaksenkov, E. (2018). Analysis of factors affecting financial inclusion: Ecosystem view. Journal of Business Research, 89, 198-205.

Kim, D. W., Yu, J. S., \& Hassan, M. K. (2018). Financial inclusion and economic growth in OIC countries. Research in International Business and Finance, 43, 1-14.

Laeven, L., Levine, R., \& Michalopoulos, S. (2015). Financial innovation and endogenous growth. Journal of Financial Intermediation, 24(1), 1-24.

Lai, J. T., Yan, I. K. M., Yi, X., \& Zhang, H. (2020). Digital financial inclusion and consumption smoothing in China. China \& World Economy, 28(1), 64-93.

Ledgerwood, J., Earne, J., \& Nelson, C. (2013). The new microfinance handbook: A financial market system perspective. Washington, DC: World Bank Publications.

Leon, F., \& Zins, A. (2020). Regional foreign banks and financial inclusion: Evidence from Africa. Economic Modelling, 84, 102116.

Li, Y., Li, C., \& Gao, Y. (2020). Voluntary disclosures and peer-to-peer lending decisions: Evidence from the repeated game. Frontiers of Business Research in China, 14, 1-26.

Lopez, T., \& Winkler, A. (2018). The challenge of rural financial inclusion: Evidence from microfinance. Applied Economics, $50(14), 1555-1577$

McKinnon, R. I. (1973). Money and capital in economic development. Washington, DC: The Brookings Institution.

Mehrotra, A. N., \& Yetman, J. (2014). Financial inclusion and optimal monetary policy. In Bank of International Settlements Working Papers, No. 476, (pp. 1-26).

Morgan, P., \& Pontines, V. (2014). Financial stability and financial inclusion. In Asian Development Bank Institute Working Papers, No.488, (pp. 1-16)

Naceur, S. B., Barajas, A., \& Massara, A. (2017). Can Islamic banking increase financial inclusion? In In Handbook of Empirical Research on Islam and Economic Life. Cheltenham: Edward Elgar Publishing.

Nanziri, E. L. (2016). Financial inclusion and welfare in South Africa: Is there a gender gap? Journal of African Development, 18(2), 109-134.

Neaime, S., \& Gaysset, I. (2018). Financial inclusion and stability in MENA: Evidence from poverty and inequality. Finance Research Letters, 24, 230-237.

Ouma, S. A., Odongo, T. M., \& Were, M. (2017). Mobile financial services and financial inclusion: Is it a boon for savings mobilization? Review of Development Finance, 7(1), 29-35.

Owen, A. L., \& Pereira, J. M. (2018). Bank concentration, competition, and financial inclusion. Review of Development Finance, $8(1), 1-17$.

Ozili, P. K. (2018). Impact of digital finance on financial inclusion and stability. Borsa Istanbul Review, 18(4), 329-340.

Pearce, D. (2011). Financial inclusion in the Middle East and North Africa. In World Bank Policy Research Working Paper No. 5610.

Peng, R., Zhao, M., \& Wang, L. (2014). Financial inclusion in the People's republic of China: Achievements and challenges. Financial Inclusion in Asia, 7, 7-43.

Rice, T., \& Strahan, P. E. (2010). Does credit competition affect small-firm finance?. The Journal of Finance, 65(3), 861-889.

Samargandi, N., Fidrmuc, J., \& Ghosh, S. (2015). Is the relationship between financial development and economic growth monotonic? Evidence from a sample of middle-income countries. World Development, 68, 66-81.

Sethi, D., \& Acharya, D. (2018). Financial inclusion and economic growth linkage: Some cross country evidence. Journal of Financial Economic Policy, 10(3), 369-385.

Sharma, D. (2016). Nexus between financial inclusion and economic growth: Evidence from the emerging Indian economy. Journal of Financial Economic Policy, 8(1), 13-36.

Shaw, E. S. (1973). Financial deepening in economic development. New York: Oxford University Press.

Sinclair, S. (2013). Financial inclusion and social financialisation: Britain in a European context. International Journal of Sociology and Social Policy, 33(11/12), 658-676.

Sparreboom, P., \& Duflos, E. (2012). Financial inclusion in the People's republic of China: An analysis of existing research and public data. In China Papers on Inclusiveness No. 7.

Tsai, K. S. (2017). FinTech and financial inclusion in China. HKUST Institute for Emerging Market Studies, No. 20

Turegano, D. M., \& Herrero, A. G. (2018). Financial inclusion, rather than size, is the key to tackling income inequality. The Singapore Economic Review, 63(01), 167-184.

World Bank (2017). Global financial inclusion (Findex) database. Retrieved from https://globalfindex.worldbank.org/

World Bank (2018). Understanding Poverty: Overview of Financial inclusion. Retrieved from https:/www.worldbank.org/en/ topic/financialinclusion/overview

World Bank (2019). Getting Credit Rank. In Doing Business Dataset Retrieved from https://datacatalog.worldbank.org/rankgetting-credit-1 most-business-friendly-regulations.

Yang, L., \& Zhang, Y. (2020). Digital financial inclusion and sustainable growth of small and micro enterprises-Evidence based on China's new third board market listed companies. Sustainability, 12(9), 1-21.

Zins, A., \& Weill, L. (2016). The determinants of financial inclusion in Africa. Review of Development Finance, 6(1), 46-57.

\section{Publisher's Note}

Springer Nature remains neutral with regard to jurisdictional claims in published maps and institutional affiliations. 